\title{
Reduction of $\mathrm{PuO}_{2}$ by $\mathrm{CO}$ and Equilibrium Partia! Pressures Above Piutonia
}

by

R. A. Kent

R. W. Zocher 
Work supported by the US Eneray Research and Development Admin. istration, Division of Nuclear Research and Applications.

Printed in the United States of America. Availacite from

National Technical Information Service

U.S. Department of Cornmerce

5285 Port Royal Road

Springfielt, VA 22161

Price: Pristed Copy $\$ 4.00$ Mictafiche $\$ 3.00$

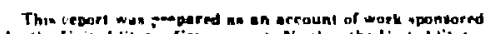

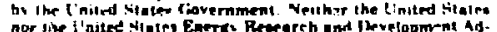

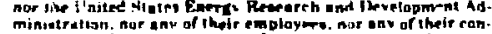

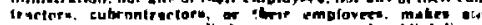

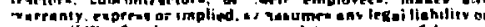

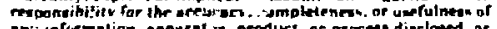

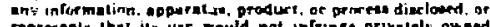

repere 
REDUCTION OF $\mathrm{PuO}_{2}$ BY CO AND EQUILIBRIUM

PARTLAL PRESSURES ABOVE PLUTONLA

by

R. A. Kent and R. W. Zocher

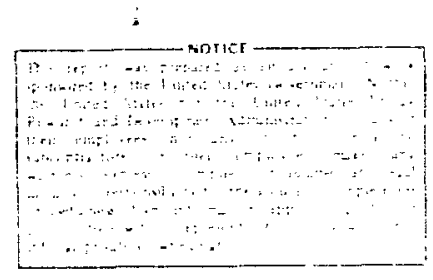

\begin{abstract}
The reduction of plutionia in flowing carbon monoxide has been determined over the range $1200-1800^{\circ} \mathrm{K}$. The experimental data confirm recently published thermodynamic functions for the plutonium-oxygen system. Equilibrium partial pressures are listed for vapor species above stoichiometric and reducea plutonia in the range $1200-1800^{\circ} \mathrm{K}$.
\end{abstract}

\title{
I. INTRODUCTION
}

Isotopic heat sources, fueled with ${ }^{238} \mathrm{PuO}_{2}\left(80 \mathrm{at} . \%{ }^{238} \mathrm{Pu}\right)$, bave been used in a nimber of space missions to supply the electrical energy required for onboard instruments. In a typical heat source, the solid ${ }^{238} \mathrm{PuO}_{2}$ fuel is encapsulated in a noble metal alloy shell that, if turn, is surrounded by graphire that provides an ablation shell during reentry and impact protection following reentry. These heat source components are generally packaged in a noble metal outer container. The heai generated by the ${ }^{238} \mathrm{FuO}_{2}$ fuel is converted to electrical energy isy means of thermoelectric devices mounted on the ouier container. Current isotopic heat sources, designed to operate with fuel surface temperatures in the range $1300-1450^{\circ} \mathrm{C}$, are contained in iridium. Advanced modulartype heat sources, currently being tested, are designed to operate with fuel surface temperatures in the range $400-1100^{\circ} \mathrm{C}$. The container material for these units will be the Pt-3008 alloy (62 wt\% Pt, $30 \mathrm{wt} \% \mathrm{Rh}$ and $8 \% \mathrm{~W})$.

Because of the relatively large amount of graphite associated with any heat source, significant quantities of carbon monoxide gas can be formed. Possible oxygen sources include oxides such as $\mathrm{SiO}_{2}$ in the thermoelectric components, oxygen or water vapor adsorbed on the graphite or container surfaces, and oxygen from the fuel. If carbon monoxide gas is formed, it can reduce the ${ }^{298} \mathrm{PuO}_{2}$ fuel stoichiometry. producing carbon dioxide gas 2.s a by-product. At a given temperature, the plutonium activity' 
(partial pressure) will increase as the fuel is reduced. This can lead to reaction with the container material to form such compounds as $\mathrm{PuIr}_{2}$ or $\mathrm{PuPt}_{55}$. Formation of such cornpounds, in turn, can lead tc failure of the container during reentry cr impact.

In these experiments, ${ }^{238} \mathrm{FuO}_{2}$ pellets were reduced in flowing $\mathrm{CO}$ Eas over the range $927-1527^{\circ} \mathrm{C}\left(1200-1800^{\circ} \mathrm{K}\right)$. The experimental results are in good agreement with values calculated from the thermodynamic functions for the $\mathrm{Pu}-\mathrm{O}$ syst $\epsilon \mathrm{m}$, reviewed and listed in a recent Los Alamos Scientific Laborato:y report. ${ }^{1}$

\section{П. EXPERIMENTAL PROCEDURES AND RESULTS}

The experimental technique was to heut weighed plutonia pellets in flowing carbon monoride gas, weigh the reduced pellets, and reoxidize the pellets to confirm the weisht reduction. The plutonia pellets $\left(80\right.$ at. $\left.{ }^{236} \mathrm{Pu}\right)$ were formed by hot pressing and were then heated at $1350^{\circ} \mathrm{C}$ in flowing $\mathrm{Ar}-\mathrm{H}_{2}{ }^{16} \mathrm{O}$ to acjust the stoichiometry to $\mathrm{PuO}_{2} \cdot 00$. The use of $\mathrm{H}_{2}{ }^{16} \mathrm{O}$ limits the $(a, n)$ reactions that occur with ${ }^{17} \mathrm{O}$ and ${ }^{18} \mathrm{O}$, and thus reduces the neutren emission rate.

The $\mathrm{CO} / \mathrm{CO}_{2}$ partial pressure ratios were "fixed" by passing the $\mathrm{CO}$ gas through a horizontal furnace containing graphite powder heated at a constam temperature. Graphite temperatures were varied from $927-1127^{\circ} \mathrm{C}$, and $\mathrm{CO}$ pressures were varied from 0.08 to 0.80 atrn. Standard air pressure at Los Alamıs is approximately $80 \%$ that at sea level. The lower CO pressures were obtained by blending the $\mathrm{CO}$ gas with dry argon before introdiction into the furnace containing the graphite.

With the $\mathrm{CC}: \mathrm{O}_{2}$ ratio fixed, the reactant gas was introduced into a second horizontal furnace containing two or more weighed ${ }^{238} \mathrm{PuO}_{2}$ pellets. Three sizes of pellets were used, $3.45,8.85$, and $15.90 \mathrm{~g}$. The pellets were heated for a specified time at a constant temperature and then removed from the firnace and weighed. The amount of reduction was calculated frorn the weight loss, assuming an atomic weight of 238.2 for the plutoniur.. A typical isotopic analysis for the ${ }^{236} \mathrm{PuO}_{2}$ fuel material is listed in Table $\mathrm{I}$. The weight iosses were confirrned by reoxidizing the pel:ets to a constant weight by again heating them at $1350^{\circ} \mathrm{C}$ in flowing $\mathrm{Ar}-\mathrm{H}_{2}{ }^{16} \mathrm{O}$. All experiments were performed in an inert atmosphere glovebox (<10 ppm oxygen).

Reaction times were varied from 6 to $96 \mathrm{~h}$ and the temperature of the fuel pellets was varied from $927-1527^{\circ} \mathrm{C}\left(1200-1800^{\circ} \mathrm{K}\right)$. Temperatures were measured with NBScalibrated $\mathrm{Pt}-\mathrm{Pt} / \mathrm{Rh}$ thermocouples and the furnaces were oper'ted with programmable controllers capable of maintaining the experimental temperatures constant to $\pm 2^{\circ} \mathrm{C}$.

For the experiments performed with the fuel pellets heated over the range $927-$ $1127^{\circ} \mathrm{C}$, the pellets were placed on $\mathrm{Pt}-3008$ sheet located within the furnace. For the experiments with the fuel pellets heated over the range $1227-2527^{\circ} \mathrm{C}$, the pellets were placed on iridium sheet. No reactions oacurred between the plutonia and the Ft -3008 or iridium during any expeximent.

The data for a typical series of experiments are summarized in Table II. For these particular experiments, the CO gas pressure was $0.09 \mathrm{~atm}$, the graphite temperature was $927^{\circ} \mathrm{C}$, and the temperature of the fuel pellets was $1127^{\circ} \mathrm{C}$. Reduction run times were $6,24.32$, and $96 \mathrm{~h}$. 
For each series u? 'xperiments, at least one reduition run was made during which the furnace containing the fuel pellets was opexated unde: a slight vacuum to ensure removal of all reactan: and product gases. Each time, the results obtained were essentially the same as when the vacuum conditions wexe not usea, probably because excess CO reactant gas was present during each reduction ruu.

Because three sizes of pellets were used, the datia for each series of experinents were normalized to determine the weight loss for an average size pellet weighing $8.850 \mathrm{~g}$ as $\mathrm{PuO}_{2} \cdot 09$. The time dependence of the normalized weight loss for each series of experiments was then calculated by the methou of least-squares. Weight loss versus time vaiues for the data listed in Table II are summarized i: Table III.

The weight loss versus time relationships for erch series of experiments were used to calculate maximum recuction values assuming a 10-yr mission for the heat source. For each series of experiments, however, the results inaicate that the liltirnate weight loss occurred in less than $1000 \mathrm{~h}$ and, in many cases, in less tinan $100 \mathrm{~h}$. The data listed in Table III indicate that a reduction rum time of $1000 \mathrm{~h}$, difficult to control in practice, would result in a weight loss only $z \mathrm{mg}$ greater than that obtained in $96 \mathrm{~h}$.

Sixty reduction runs were made using $118{ }^{238} \mathrm{PuO}_{2}$ sample pellets. The ultimate, or equilibrium, weight loss values are listed and compared to calculated values: in the following section.

\section{THERMODYNAMIC CALCULATIONS}

For the equations and calculations that follow, the symbol ( ) is used to represent gaseous species and $<>$ is used to represent solids.

Markin and Rand, ${ }^{2}$ usirg an EMF technique, measured the oxygen potentials above the single-phase plutonium oxides between $\left\langle\mathrm{PuO}_{1 \cdot 61}\right\rangle$ and $\left\langle\mathrm{PuO}_{2}\right\rangle$ over the range 600$1100^{\circ} \mathrm{C}$. In addition, published vapor pressure data for plutcinium $3,4,5$ and for the plutonium-oxygen system ${ }^{1}, 6,7,8,9,10$ have been reviewed in a recent Los Alamos Scientific Laboratory report. ${ }^{1}$ Previous thermodynamic calculations pertaining to the plitonium-oxygen system have involved an extrapolation of the Martin and

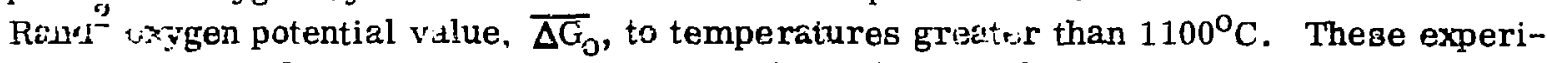
mente were porformed not only to measure the reduction of $\left\langle\mathrm{PuO}_{2 \cdot 0}\right\rangle$ in flowing $(\mathrm{CO})$, but also to confirm the pliblished values ${ }^{2}$ for $\overline{\Delta G_{0}}$, and to determine values for $\overline{\Delta G}_{0}$ at temperatures graizer than $1100^{\circ} \mathrm{C}$,

Free energy of formation values ${ }^{1}$ for ( $\mathrm{Pu}$ ) and $\left\langle\mathrm{PuO}_{2}\right\rangle$, used in the zollowing calculations, are listed in Table IV. Also listed in Table IV are free ener. of formation values for $(\mathrm{O}),(\mathrm{CO})$, and $\left(\mathrm{CO}_{2}\right)$, tatien from the JANAF Tables. 1 The free energies of formation for (PuO) and $\left(\mathrm{PuO}_{2}\right)$ are given ${ }^{6}$ by

$$
\Delta \mathrm{G}_{\mathrm{f}}(\mathrm{PuO})=-290 \mathrm{c0}-12.1 \mathrm{~T},{ }^{\circ} \mathrm{K}(\mathrm{cal} / \mathrm{mole})
$$

and

$$
\left.\Delta \mathrm{G}_{\mathrm{f}}\left(\mathrm{PuO}_{\mathrm{z}}\right)=-113100+4.35 \mathrm{~T},{ }^{\circ} \mathrm{K} \text { (cal.mole }\right)
$$

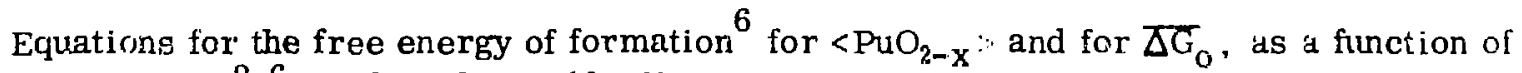
composition, 2,6 are listed in Table $V$. 
7. 3 ? 3 rtial pressures of $\left(\mathrm{O}_{2}\right)$, above the reduced fuel pellets, were calculated in the following nimier. The partial nressure of $\left(\mathrm{CO}_{2}\right)$ is related to the experimental (CO) pressure according to the reaction

$$
2(\mathrm{CO})=\left[\because \%+\left(\mathrm{CO}_{2}\right) .\right.
$$

For Eq. (3)

$$
\begin{aligned}
\Delta \mathrm{G} & =\Delta \mathrm{G}_{\mathrm{f}}\left(\mathrm{CO}_{2}\right)-2 \Delta \mathrm{G}_{\mathrm{f}}(\mathrm{CO}) \\
& =-\mathrm{RT} \text { \&n } \mathrm{K} \\
& =-2.3 \mathrm{RT}\left(\log \mathrm{P}_{\mathrm{CO}}-2 \log \psi_{\mathrm{CO}_{2}}\right)
\end{aligned}
$$

where $\mathrm{R}$ is the gas consta 1 t, $1.98726 \mathrm{cal} / \mathrm{deg}$ mole, and $\mathrm{T}$ is the graphite temperature in degrees Kel vin.

The partial pressures of $\left(\mathrm{O}_{2}\right)$ above the fuel pellets are determined from the $(\mathrm{CO})$ and $\left(\mathrm{CO}_{2}\right)$ partial pressures according to the reaction

$$
2\left(\mathrm{CO}_{2}\right)=2(\mathrm{CO})+\left(\mathrm{O}_{2}\right)
$$

For Eq. (5)

$$
\begin{aligned}
\Delta \mathrm{G} & =2 \Delta \mathrm{G}_{\mathrm{f}}(\mathrm{CO})-2 \Delta \mathrm{G}_{\mathrm{f}}\left(\mathrm{CO}_{2}\right) \\
& =-2.2 \mathrm{RT}\left(2 \log \mathrm{P}_{\mathrm{CO}}+\log \mathrm{P}_{\mathrm{O}_{2}}-2 \log \mathrm{P}_{\mathrm{CO}_{2}}\right)
\end{aligned}
$$

where $\mathrm{T}$ is the temperature of the fuel peilst in degrees Kelvin.

The $\left(\mathrm{O}_{2}\right)$ partial pressures above the reduced fuel, obtained from Eq. (6), can then be compared to the $\left(\mathrm{O}_{2}\right)$ partial pressures calculated, as a function of composition, from the values of $\overline{\Delta G_{0}}$ listed in Table $V$. The partial pressure of $(O)$ above $\left\langle\mathrm{PuO}_{2-\mathrm{X}}\right\rangle$ is given by

$$
{\overline{\Delta G_{o}}}=2.3 \mathrm{RT} \log \mathrm{P}_{\mathrm{o}} .
$$

Thie partial fressure of $\left(\mathrm{O}_{2}\right)$ is related to that for $(0)$ according to the reaction

$$
(\mathrm{O})=\frac{1}{1}\left(\mathrm{O}_{2}\right) \text {. }
$$


For Eq. (8)

$$
\begin{aligned}
\Delta G & =-\Delta G_{f}(O) \\
& =\frac{-2.3 F_{i} T}{2} \log P_{O_{2}}+2.3 R T \log P_{C O} \\
& =\frac{-2.3 R T}{2} \log P_{O_{2}}+\overline{\Delta G}_{O} .
\end{aligned}
$$

As an example, the equilibrium (10-yr) stoichiometry listed in Table III is $\left.<\mathrm{PuO}_{1}=960\right\rangle$. With the graphite at $927^{\circ} \mathrm{C}$ and the $(\mathrm{CO})$ pressure at $0.08 \mathrm{~atm}$, the partial pressure of $\left(\mathrm{CO}_{2}\right)$, calculated from. Eq. (4), is $1.23 \times 10^{-4}$ atm. The equilibrium pressure of $\left(\mathrm{O}_{2}\right)$ above $\left\langle\mathrm{PuO}_{1} \cdot \varsigma_{6 \mathrm{C}}\right\rangle$, at $1127^{\circ} \mathrm{C}$, is then calculated from Eq. $(6)$ to be $2.22 \mathrm{x}$ $10^{-18} \mathrm{~atm}$. The $\overline{\Delta G}_{\mathrm{o}}$ value's listed in Table $\mathrm{V}$, combined with Eq. (9), yield an equilibrium $\left(\mathrm{O}_{2}\right)$ partial pressure of $2.82 \times 10^{-18}$ atm above $<\mathrm{PuO}_{1} \cdot 953>$ at $1127^{\circ} \mathrm{C}$, in good agreement with the experimental value of $\left\langle\mathrm{PuO}_{1} \cdot 960\right\rangle$.

The experimental vialues tor the reduction of $\left\langle\mathrm{PuO}_{2}\right\rangle$ by $(\mathrm{CO})$ are summerized and compared to the saiculated values in Table VI. The experimental values listed are those at equilibrium (end of a $i(r y I$ mission) calculated from the least-squares fit of the weight loss versus time for" each series of experiments. "The calculated values listed in Table VI were obtained by combihing Eqs. (4), (6), and (9) with the $\Delta G_{0}$ values listed in Table $V$. All calculated and experimental weight losses have been normalized to those for the average sized experimental pell ot weighing $8.850 \mathrm{~g}$ as $\left\langle\mathrm{PuO}_{2 \cdot 00}\right\rangle$.

The weight losses calculated from the thermodynamic functions are slightly less than the experimeatial values at low fuel temperatures and slightly greater at the higher fuel temperatures. The overall agreement, however, is very good and is within the standard deviations zalculated from the least-squares fits of the experimental data. These results confirm the $\bar{\Delta}_{\mathrm{O}}^{r}$ values determined by Markin and Rand ${ }^{2}$ and inaicate that

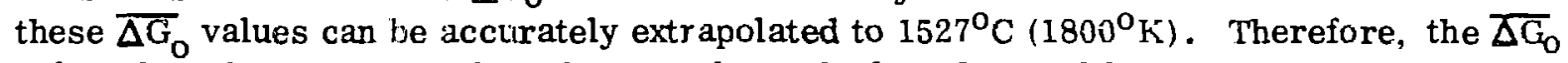

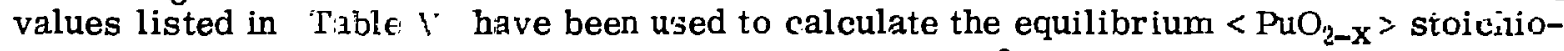
metries for a variety of graphite temperatures $\left(827-1527^{\circ} \mathrm{C}\right)$, fuel temperatures $(927-$ $\left.1527^{\circ} \mathrm{C}\right)$, and $(\mathrm{CO})$ pressures $(0.008-8.0 \mathrm{~atm})$. These results are summarized in Tables VII-XIII.

\section{CALCULATED EQUILIBRIUM PARTIAL PRESSURES ABOVE $<\mathrm{PuO}_{\mathbf{z}^{-} \mathrm{Y}}>$}

The major uncertainty assjciated with the thermodynamic functions listed in Tables IV and $V$ has resulted from the necessity to extrapolate the $\overline{\Delta G}_{0}$ values to temperatures greater than $1100^{\circ} \mathrm{C}$. The results discussed in the previous section indicate that the $\overline{\Delta G_{0}}$ values listed in Table $V$ are indee ${ }^{2}$ accurate over the range $927-1527^{\circ} \mathrm{C}\left(1200-1800^{\circ} \mathrm{K}\right.$. Therefore, it is possible, using the thermodynamic functions listed in Tables IV and $V$ and Eqs. (1) and (2), to calcuiate the equilibrium partial pressure values for all vapor species above $\left\langle\mathrm{PuO}_{2 \rightarrow \mathrm{x}}\right\rangle$ over this same temperature range. 
The partial pressur $\ni$ of $(O)$ is given iy Eq. (7), that for $\left(\mathrm{O}_{2}\right)$ by Eq. (9). The partial pressure of ( $\mathrm{Fu}) \mathrm{c}$ an bu obtained from the reaction

$$
\left\langle\mathrm{PuO}_{2-\mathrm{X}}\right\rangle=(\mathrm{Pu})+(2-\mathrm{x})(\mathrm{O}) .
$$

For Eq. (10)

$$
\begin{aligned}
\Delta G & =\Delta G_{f}(P u)+(2-x) \Delta G_{f}(O)-\Delta G_{f}<P O_{2-x}> \\
& =-2.3 R T\left[\log P_{P u}+(2-x) \log P_{O}\right] .
\end{aligned}
$$

Similariy, the partial pressure of ( $\mathrm{PuO})$ can be obtained from the reaction

$$
\left\langle\mathrm{PuO}_{p-\mathrm{x}}\right\rangle=(\mathrm{PuO})+(1-\mathrm{x})(\mathrm{O}) .
$$

For Eq. (12)

$$
\begin{aligned}
\Delta G & =\Delta G_{f}(P u O)+(1-x) \Delta G_{f}(O)-\Delta G_{f}\left\langle P O_{2-x}\right\rangle \\
& =-2.3 R T\left[\log P_{P u O}+(1-x) \log P_{O}\right] .
\end{aligned}
$$

Finally, the partial pressure of $\left(\mathrm{PuO}_{2}\right)$ can be obtained from the reaction

$$
<\mathrm{PuO}_{2-\mathrm{x}}>+\mathrm{x}(\mathrm{O})=\left(\mathrm{PaO}_{2}\right) .
$$

For Eq. (14)

$$
\begin{aligned}
\Delta G & =\Delta G_{f}\left(P_{u O} O_{2}\right)-\Delta G_{f}\left\langle P_{2 u O_{2-x}}\right\rangle-x \Delta G_{f}(O) \\
& =-2.3-T\left[\log P_{\mathrm{PuO}_{2}}-x \log P_{O}\right] .
\end{aligned}
$$

Calculated values for the partial pressures of $(\mathrm{O}),\left(\mathrm{O}_{2}\right),(\mathrm{Pu}),(\mathrm{PuO})$, and $\left(\mathrm{PuO}_{2}\right)$ above various $\left\langle\mathrm{PuO}_{2-\mathrm{X}}\right\rangle$ compositions, in the range $927-1527^{\circ} \mathrm{e}\left(1200-1800^{\circ} \mathrm{K}\right)$, are listed in Tables XIV-XX.

v. REACTION OF PLUTONIUM VAPOR WITH IRIDIUM AND THE Pt-3008 ALLOY

Current isotopic heat scurces designed to operate with fuel surface temperatures in the range $1300-1450^{\circ} \mathrm{C}$ are contained in iridium. Advanced modular-type heat sourr os, currently being tested, are designed to operate with fuel temperatures in the range 900$1100^{\circ} \mathrm{C}$. The container material for these units will be the Pt-3008 alloy (62 wt\% P., 30 $\mathrm{wt} \% \mathrm{Rh}$, and $\varnothing \mathrm{wt} \% \mathrm{w})$,

The values listed in Tables VII-XIII indicate that if sufficient quantities of (CO) are present the $\left\langle\Gamma^{\prime} \mathrm{O}_{2}\right\rangle$ fuel can be significantiy reduced. The values listed in Tables $\mathrm{XIV}-\mathrm{XX}$ indicate the increase in the partial pressure of $(\mathrm{Pu}) \approx \mathrm{s}$ the $<\mathrm{PuO}_{2}>$ is reduced. 
This is of concern because, as the ( $\mathrm{Pu}$ ) pressure increases, it becomen more likely that the $(\mathrm{Pu})$ can react with the noble metal container.

The vapor pressure of ( $\mathrm{Pu})$ above $\left\langle\mathrm{PuIr}_{2}\right\rangle$ is given ${ }^{12}$ by the equation

$$
\log P_{P u}=4.26-26529 / \mathrm{T},{ }^{\circ} \mathrm{K}
$$

By combining Eq. (16) with the (Pu) partial pressures listed in Tebles XIV-XX, one can determine if the compound $\left\langle\mathrm{Puir}_{2}\right\rangle$ will form. So long as the vapor pressure of (Fu) above $\left.<\mathrm{PuIr}_{2}\right\rangle$ is greater than that above $\left\langle\mathrm{PuO}_{2-\mathrm{x}}\right\rangle$, no reaction can occur.

Feterson ${ }^{13}$ has studied the phase relationships and vaporization behavior of plutonium combined with the various components of the Pt-3008 alloy. To date, he has determined the (Pu) pressure above four compnunds; < $\left.\mathrm{PuP}_{t_{3}}\right\rangle,\left\langle\mathrm{PuPt}_{4}\right\rangle,\left\langle\mathrm{PuPt}_{5}\right\rangle$, and $<\mathrm{PuRh}_{3}>$. The (Pu) pressures above these compounds are given by the following equations:

$$
\begin{aligned}
& <\mathrm{PuPt}_{3}>, \log \mathrm{P}_{\mathrm{Pu}}=5.04-26940 / \mathrm{T},{ }^{\circ} \mathrm{K} \\
& <\mathrm{PuPt}_{4}>, \log \mathrm{P}_{\mathrm{Pu}}=1.11-21303 / \mathrm{T},{ }^{o_{\mathrm{K}}} \\
& <\mathrm{PuPt}_{5}>, \log \mathrm{P}_{\mathrm{Pu}}=-2.16-17: 78 / \mathrm{T},{ }^{o_{\mathrm{K}}}
\end{aligned}
$$

and

$$
<\mathrm{PuRh}_{3}>, \log \mathrm{P}_{\mathrm{Pu}}=7.856-31859 / \mathrm{T},{ }^{\circ} \mathrm{K}
$$

Eoxations (17), (18), (19), and (20) can be combined with the (Pu) partial pressure values listed in Tables XIV-XX to determine if the various compc:inds will form.

Compositions of $\left\langle\mathrm{PuO}_{2-\mathrm{x}}\right\rangle$ that lead to formation of the $\mathrm{Pu}-\mathrm{Ir}, \mathrm{Fu}-\mathrm{Pt}$, and $\mathrm{Pu}-\mathrm{Rh}$ compounde are listed in Table XXI. These values, in turn; can be combined with those listed in Tables VII-XIII to decermine if the (CO), present in the heat source, can reduce the $\left\langle\mathrm{PuO}_{2}\right\rangle$ fuel to tne required stoichiometries.

The results of a recent study 14 indicate thiat most of the (CO) present in a heat source is probably due to degassing of the graphite components. Furthermore, the quantities and pressures of (CO) likely to be encountered in a vented heat source are such that the $(\mathrm{CO})$ should not reduce the $\left\langle\mathrm{PuO}_{2}\right\rangle$ sufficiently to cause reaction with the $\mathrm{Pt}-3008$ alioy in the expected operating temperature range (below $1100^{\circ} \mathrm{C}$ ). Similarly, so long as the fuel $t: s$ mperature is higher than the graphite temperature, no reaction should occur with iridium below fuel temperatures of $1450^{\circ} \mathrm{C}$. Finally, although higher graphite tem.peratures can occur during reentry, the exposure times are much too short (5-10 min; to produce significant reduction of the fuel. 


\section{SUMMARY}

The rectuction of $\left\langle\mathrm{PuO}_{2}\right\rangle$ in flowing (¿O) has been determined o:rer the range 927$1527^{\circ} \mathrm{C}\left(1200-1800^{\circ} \mathrm{K}\right)$. The thermodynamic functions listed in Tables $\mathrm{IV}$ and $\mathrm{V}$ lead to calculated $\mathrm{C} / \mathrm{Pu}$ ratios that are in good agreement with the experimental data. Thus, these thermodynamic functions can be used to prculict accurately the leduction of $\left\langle\mathrm{PuO}_{2}\right\rangle$ by $(\mathrm{CO})$ over a wide range of graphite and fuel temperatures and (CO) pressures. Calculated reduction values are listed in Tables VII-XIII. In addition, the thermodynamic functions listed in Tables IV and V can be used to calculate the equilibrium partial pressure values of all vapor species above $\left\langle\mathrm{PuO}_{2-\mathrm{x}}\right\rangle$. These calculated values are listed in Tables XIV-XX. Finally, the quantities of $(\mathrm{CO})$ likely to exist in a typical vented heat source are sich that reduction of the fuel, sufficient to promote reaction with iridium or Pt-3008 containers, is unlikely in the expected operational temperature ranges.

\section{ACKNOWLEDGMENT'S}

The authors are indebted to S. McClanahan, CMB-11, for assistance with the carbon monoxide reduction experiments.

\section{REFERENCES}

1. R. A. Kent, "Thermodynamic Analysis of MHW Space Electric Power Genorator," Los Alamos Scientific Laboratory report LA-5202 •MS (March 1973).

2. T. L. Markin and M. H. Rand, "Thermodynamic Data for Plutonium Oxides, "in Thermodynamics, Vol, 1 (IAEA, Vienna, 1966), pp. 144-156.

3. T. E. Phipps, G. W. Sears, R. L. Seifert, and O. C. Simpson, "Vapor Pressure of Liquid Plutonium," Proc. UN Int. Conf., PUAE I, (1956), pp. 382-386.

4. R. N. R. Mulford, "The Vapor Pressure of Plutonium," in Thermodynamics, Vol. 1 (IAEA, Vienna, 1966), pp. 231-241.

5. R. A. Kent, "Mass Spectrometric Studies of Plutonium Compounds at High Temperatures, III. The Vapor Pressure of Plutonium," High Temp. Sci. 1,169 (1969).

6. R. J. A ckermann, R. L. Faircloth, and M. H. Rand, "Thermorynamic Study of the Vaporization Behavior of the Gubstoichiometric Plutonium Dioxide Phase, " $J$. Phys. Chem. 70, 3698 (1966).

7. R. W. Ohse and C. Ciani, "Evaporation Behavior and High-Temperature Thermal Analysis of Substoichiometric Plutonium Oxide for $1.51<\mathrm{P} / \mathrm{Pu}<2.00$, " in Thermodynamics of Nuclear Materials 1967 (IAEA, Vienna, 1968), pp. 545-557.

8. D. R. Messier, "Evaporation of Hypostoichiometric Plutonium Dioxide from $2070^{\circ}$ to $2380^{\circ} \mathrm{K}$, J. Am. Ceram. Soc. 51, 710 (1968). 
9. J. E. Bactles, J. W. Feishus, and W. A. Shinn, "Volatilization Studies of Plutonium Compounds by Mass Spectrometry. Plutonium-Orygen Syst $\because \mathrm{m}$, " Argonne National Iaboratory report ANL-75?5, (1968).

10. T. E. Pinipps, G. W. Stars, and O. C. Simpson, "The Yslatility of Plutonium Dioxide, "J. Chem. Phys. 18, 724 (1950).

11. JANAF Thermochemical Tables, Second Edition, D. R. Stull and H. Prophet, Eds. Office of Standard Reference Data, National Bureal of Standar $r^{*}$, NSRDS-NBS̃ 37, (1971).

12. W. M. Olson, Los Alamos Scientific Laborato $z y$, unpublished data, 1972.

13. D. E. Peterson, Los Alamos Scientific Laboratory, unpublished data, 1976.

14. D. E. Peterson and R. N. R. Mulford, "Analysis of Carbon Monoxide Production in Multihundred-Watt Heat Sources, " Los Alamos Scientific Labciatory report iAA3676-MS (June 1976).

TABLE I

ISOTOPIC ANALYSIS FOR ${ }^{238} \mathrm{PuO}_{2}$

FUEL FEED MATERIAL

\begin{tabular}{|c|c|}
\hline Isotope & $\mathrm{wt}^{\mathrm{a}}{ }^{\mathrm{a}}$ \\
\hline${ }^{238} \mathrm{Pu}$ & 80.02 \\
\hline${ }^{259} \mathrm{Pu}$ & 16.33 \\
\hline${ }^{240} \mathrm{Pu}$ & 2.66 \\
\hline${ }^{241} \mathrm{Pu}$ & 0.76 \\
\hline${ }^{242} \mathrm{Pu}$ & 0.23 \\
\hline
\end{tabular}


TABLE II

REDUCIIUN OF $\mathrm{PuO}_{2}$ AT $1127^{\circ} \mathrm{C}$

BY CO AT 0.08 ATM

(grapnite at $927^{\circ} \mathrm{C}$ )

\begin{tabular}{|c|c|c|c|c|}
\hline \multirow{2}{*}{$\begin{array}{l}\text { Time } \\
\text { (h) }\end{array}$} & \multirow[b]{2}{*}{ Pellet No. } & \multicolumn{2}{|c|}{ Weight (g) } & \multirow{2}{*}{$\begin{array}{c}\text { Stoichiometry } \\
(\mathrm{O} / \mathrm{Pu})\end{array}$} \\
\hline & & Oxidized $^{d}$ & Reduced & \\
\hline \multirow[t]{5}{*}{6} & $135-2$ & 8.8523 & 8.8473 & 1.990 \\
\hline & $145-1$ & 3.4465 & 3.4451 & 1,993 \\
\hline & $135-2$ & 8.8473 & 8.8454 & 1.996 \\
\hline & . 145-2 & 3.4517 & 3.4485 & \pm .984 \\
\hline & & & & $1.991 \pm 0.005$ \\
\hline \multirow{2}{*}{24} & $135-2$ & 8.8480 & 8.8365 & 1.978 \\
\hline & $145-2$ & 3.4498 & 3.4411 & 1.960 \\
\hline \multicolumn{2}{|c|}{ and } & & & $1.969 \pm 0.012$ \\
\hline \multirow[t]{3}{*}{32} & $134-3$ & 8.8484 & 8.8365 & 1.973 \\
\hline & $.145-3$ & 3.4492 & 3.4432 & 1.971 \\
\hline & & & & $1.972 \pm 0.002$ \\
\hline \multirow[t]{2}{*}{$32-v^{b}$} & $135-1$ & 8.8467 & $8.832 \pi$ & 1.973 \\
\hline & $145-1$ & 3.4478 & 3.4410 & 1. 967 \\
\hline \multirow{3}{*}{96} & $\ldots \ldots$ & & & $1.965 \pm 0.004$ \\
\hline & $135-2$ & 8.8520 & 8.8342 & 1.966 \\
\hline & $145-2$ & 3.4502 & 3.4429 & 1.964 \\
\hline & & & & $1.965 \pm 0.002$ \\
\hline
\end{tabular}

ayerage of initial and reoxidized weights.

$b_{\text {Slight vacuum on furmace. }}$ 
TABLE IIİ

FEDUCTION OF PUO $A T 1127^{\circ} \mathrm{C}$

VS

TMN

(CO piessure at 0.08 atm, graphite at $927^{\circ} \mathrm{C}$ )

\begin{tabular}{rcccc}
$\begin{array}{c}\text { Time } \\
\text { (h) }\end{array}$ & $\begin{array}{c}\text { Stoichiometry } \\
(\mathrm{O} / \mathrm{Pu})\end{array}$ & & \multicolumn{2}{c}{ Weight Loss $(\mathrm{g})^{\mathrm{a}}$} \\
\hline 6 & 1.392 & & $\frac{\text { Calc. }}{\mathrm{b}}$ & Obs. \\
24 & 1.973 & & 0.004 & 0.005 \\
32 & 1.970 & 0.014 & 0.017 \\
96 & 1.964 & 0.019 & 0.015 \\
1000 & 1.960 & 0.021 & \\
$10 \mathrm{yr}$ & 1.960 & 0.021 &
\end{tabular}

aBased on average size pellet $\left(8.850 \mathrm{~g}\right.$ as $\left.\mathrm{DuO}_{2} \cdot 00\right)$.

is Calculated from least-squares if of dite $(8.850 \mathrm{~g}$ pellet), $\ln (g$ lost $)=(-9.57 \pm 1.53) /$ time $(\mathrm{h})-(3.85 \pm 0.15)$. 
TABะE IV

FREF. ENERGIES OF FORNATION

(kcal/mole)

Temp
$\frac{\left({ }^{\circ} 1\right)}{298}$
1200
1300
1490
1500
1600
1700
1800

$\begin{array}{lllll}\frac{(\mathrm{O})}{55.395} & \frac{(\mathrm{CO})}{-32.783} & \frac{\left(\mathrm{CO}_{2}\right)}{-94.265} & \frac{(\mathrm{Pu})}{74.32} & \frac{\left\langle\mathrm{MuO}_{3}\right\rangle}{-239.54} \\ 41.755 & -52.049 & -94.681 & 52.73 & -200.92 \\ 40.186 & -54.126 & -94.701 & 50.52 & -196.79 \\ 38.611 & -56.189 & -94.716 & 48.31 & -192.68 \\ 37.032 & -58.241 & -94.728 & 46.10 & -1.83 .54 \\ 35.448 & -60.284 & -94.739 & 43.38 & -184.61 \\ 33.862 & -62.315 & -94.746 & 41.63 & -180.65 \\ 32.271 & -34.337 & -94.750 & 39.38 & -176.7\end{array}$

TABLF $V$

FREE ENERGIES OF FORMLTION AND PARTLAL MOLAR FREE ENERGIES OF ATOMIC OXYGEN FOR SOLID PLUTCI WM OXIDES

\begin{tabular}{|c|c|c|c|c|}
\hline \multirow[b]{2}{*}{ Species } & \multicolumn{2}{|c|}{$\begin{array}{c}\Delta \mathrm{G}_{\mathrm{f}}^{\mathrm{o}}=\mathrm{A}+\mathrm{BT},{ }^{\mathrm{o}} \mathrm{K} \\
\quad(\mathrm{cal} / \text { mole })\end{array}$} & \multicolumn{2}{|c|}{$\begin{array}{c}\overline{\Delta \bar{G}_{0}}=A+B l,{ }_{K} \\
(\text { cal } / \text { mole })\end{array}$} \\
\hline & A & B & 1 & B \\
\hline$\left\langle\mathrm{PuO}_{2} \cdot 00\right\rangle$ & \multicolumn{2}{|c|}{ Suc Table IV } & $-20<750$ & $8 \% .7$ \\
\hline$\left\langle\mathrm{PuO}_{1 \cdot 9 R_{i}}\right\rangle$ & -246700 & 39.0 & -181750 & 63.4 \\
\hline$\left\langle\mathrm{PuO}_{1 \cdot 95}\right\rangle$ & -243100 & 37.6 & -178000 & 52.0 \\
\hline$\left\langle P u O_{1 \cdot 92}\right\rangle$ & -239700 & 36.4 & $-i \div 3750$ & 54.1 \\
\hline$\left\langle\mathrm{PuO}_{\mathbf{1}} \cdot 90\right\rangle$ & -237500 & 35.7 & -171150 & 50.8 \\
\hline$\left\langle\mathrm{PuO}_{1 \cdot 85}\right\rangle$ & -232100 & 34.1 & -164250 & 43.4 \\
\hline$\left\langle\mathrm{PuO}_{1 \cdot{ }_{B 0}}\right\rangle$ & -2271.00 & 32.9 & -157500 & 36.1 \\
\hline$\left\langle\mathrm{PuO}_{1 \cdot 75}\right\rangle$ & -222500 & 32.1 & -151500 & 29.5 \\
\hline$\left\langle\mathrm{PuO}_{1 \cdot 70}\right\rangle$ & -218000 & 31.5 & -149250 & 26.5 \\
\hline$\left\langle\mathrm{PuO}_{2} \cdot{ }_{65}\right\rangle$ & -213600 & 31,0 & -150250 & 26.1 \\
\hline$\left\langle\mathrm{PuO}_{1 \cdot 6 !}\right\rangle$ & -210000 & 30.6 & 153000 & 26.9 \\
\hline$\left\langle\mathrm{PuG}_{1} \cdot 5_{0}\right\rangle$ & -96300 & 29.6 & -153000 & 26.9 \\
\hline
\end{tabular}


TABLE VI

REDUCTION OF PuO $\mathrm{P}_{2}$ : CO

CALCUIATED VS OBSERVEA :AEUES

\begin{tabular}{|c|c|c|c|c|c|c|}
\hline \multirow{2}{*}{\multicolumn{2}{|c|}{ Temperature $\left({ }^{\circ} \mathrm{C}\right)$}} & \multirow{3}{*}{$\begin{array}{l}\mathrm{P}_{\mathrm{CO}} \\
\text { (atm) }\end{array}$} & \multicolumn{2}{|c|}{ Calcilated } & \multicolumn{2}{|c|}{ Observed $^{\mathrm{a}}$} \\
\hline & & & & Weight $^{b}$ & & Weight \\
\hline $\mathrm{P}=\mathrm{O}_{2}$ & Graphite & & $\mathrm{G} / \mathrm{Pu}$ & Loss $(\mathrm{g})$ & $\mathrm{O} / \mathrm{Pu}$ & $\operatorname{Loss}(g)$ \\
\hline \multirow[t]{2}{*}{927} & 927 & 0.08 & 1.999 & $0.00 ?$ & 1.994 & 0.003 \\
\hline & & 0.80 & 2.000 & 0.000 & 1.997 & 0.002 \\
\hline \multirow[t]{2}{*}{1027} & 927 & $0.0 \bar{s}$ & 1.989 & 0.006 & 1.979 & 0.011 \\
\hline & & 0.80 & 1.999 & 0.001 & 1.995 & 0.003 \\
\hline \multirow[t]{2}{*}{1127} & 927 & 0.03 & 1.953 & 0.025 & 1.960 & 0.021 \\
\hline & & 0.80 & 1.992 & 0.004 & 1.979 & 0.011 \\
\hline \multirow[t]{2}{*}{1227} & 1027 & 0.08 & 1.879 & 0.063 & 1.851 & 0.078 \\
\hline & & 0.80 & 1,947 & 0.028 & 1.952 & 0.025 \\
\hline \multirow[t]{2}{*}{1327} & 1027 & 0.08 & 1.852 & $\therefore .078$ & 1.867 & 0.069 \\
\hline & & 0.80 & 1.9 .20 & 0.04 .2 & 1.910 & 0.047 \\
\hline \multirow[t]{3}{*}{1427} & 927 & 0.08 & 1.870 & 0.068 & 1.878 & 0.064 \\
\hline & 1027 & 0.08 & 1.332 & 0.088 & 1.846 & 0.081 \\
\hline & 1127 & 0.80 & 1.868 & 0,069 & 1.868 & 0.069 \\
\hline \multirow[t]{2}{*}{1.527} & 1127 & 0.08 & 1.755 & 0.128 & 1.770 & 0.121 \\
\hline & 1127 & 0.80 & 1.823 & 0.093 & 1.810 & 0.084 \\
\hline
\end{tabular}

${ }^{a}$ Equilibrium (10-yr) values ohtained trom least-squares fit of reduction vs tiine.

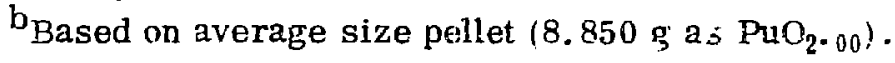


TABLE YII

CALCULATED REDUCTION OF $\mathrm{PuO}_{2}$ BY CO$\mathrm{PuO}_{2} \mathrm{~A}^{\mathrm{r}} 9227^{\circ} \mathrm{C}\left(1200^{\circ} \mathrm{K}\right)$

Graphite

Temperature $\left({ }^{\circ} \mathrm{C}\right)$

827

927

1.027

1127

1227

1327

$14 \div 7$

1527
Equilibrium Stoichoimetry $(\mathrm{O} / \mathrm{Pu})$

\begin{tabular}{llll}
\hline \multicolumn{4}{c}{ CD Pressure (atw) } \\
\hline$\underline{0.008}$ & $\frac{0.08}{2.00}$ & $\underline{0.8}$ & $\underline{8.0}$ \\
2.00 & 2.00 & 2.00 & 2.00 \\
1.98 & 2.00 & 2.00 & 2.00 \\
1.93 & 1.99 & 2.00 & 2.00 \\
1.88 & 1.98 & 2.00 & 2.00 \\
1.82 & 1.94 & 1.99 & 2.00 \\
1.77 & 1.90 & 1.99 & 2.00 \\
1.72 & 1.87 & 1.97 & 2.00 \\
1.66 & 1.83 & 1.94 & 2.00
\end{tabular}

TABLE VIII

CALCULATED REDUCTION CF $\mathrm{PuO}_{2} \mathrm{BY} \mathrm{CO}-$ $\mathrm{PuO}_{2}$ AT $1027^{\circ} \mathrm{C}\left(1300^{\circ} \mathrm{K}\right)$

Graphite

Temperature

$\left({ }^{\circ} \mathrm{C}\right)$

827

927

1027

1127

1227

1327

1427

1527
Equilibrium Stoichiometry (O/Pu) CO Pressure (atm)

\begin{tabular}{llll}
\hline 0.008 & $\underline{0.08}$ & $\underline{0.80}$ & \multicolumn{8}{c}{0}
\end{tabular}

$\begin{array}{llll}1.98 & 2.00 & 2.00 & 2.00\end{array}$

1.92

1.99

2.00

2.00

1.87

1.96

1.99

2.00

1.81

1.91

1.99

2.00

1. 77

$1.88 \quad 1.97$

1.99

1.72

1.84

1.94

1.99

1.66

$1.81 \quad 1.91$

1.99

1.62

1.78

1.89

1.97 
TABLE $\mathrm{L}$

CALCULATED REDUCTION OF $\mathrm{PuO}_{2} \mathrm{BY} \mathrm{CO}-$ $\mathrm{PuO}_{2}$ AT $1127^{\circ} \mathrm{C}\left(1400^{\circ} \mathrm{K}\right)$

\begin{tabular}{|c|c|c|c|c|}
\hline \multirow{3}{*}{$\begin{array}{c}\text { Graphite } \\
\text { Temperature } \\
\left(^{\circ} \mathrm{C}\right)\end{array}$} & \multicolumn{4}{|c|}{ Equilibrium Stoichiometry $(\mathrm{O} / \mathrm{Pu})$} \\
\hline & \multicolumn{4}{|c|}{ CO Pressure (atmi) } \\
\hline & 0.008 & 0.08 & 0.80 & 8.0 \\
\hline 827 & 1.93 & 1.99 & 2.00 & 2.00 \\
\hline 927 & 1.88 & 1.95 & 1.99 & 2.00 \\
\hline 1027 & 1.82 & 1.91 & 1.97 & 2.00 \\
\hline 1127 & 1.78 & 1.87 & 1.95 & 1.99 \\
\hline 1227 & 1.73 & 1.84 & 1.92 & 1.98 \\
\hline 1327 & 1.67 & 1.81 & 1.90 & 1.97 \\
\hline 1427 & 1.62 & 1.77 & 1.87 & 1.94 \\
\hline 1527 & $1.50+\ell$ & 1. 74 & 1.84 & 1.92 \\
\hline
\end{tabular}

TABLE $X$

CALCULATED REDUCTION OF $\mathrm{PuO}_{2}$ BY CO$\mathrm{PuO}_{2} \mathrm{AT} 1227^{\circ} \mathrm{C}\left(1500^{\circ} \mathrm{K}\right)$

\begin{tabular}{c}
$\begin{array}{c}\text { Graphite } \\
\text { Temperature } \\
\left({ }^{\mathrm{o}} \mathrm{C}\right)\end{array}$ \\
\hline 927 \\
927 \\
1027 \\
1127 \\
1227 \\
1327 \\
1427 \\
1527
\end{tabular}

\begin{tabular}{|c|c|c|c|}
\hline \multicolumn{4}{|c|}{ CO Pressure (atm) } \\
\hline 0.008 & 0.08 & 0.8 & 8.0 \\
\hline 1.90 & 1.96 & 1.99 & 2.00 \\
\hline 1.84 & 1.92 & 1.98 & 1.99 \\
\hline 1.80 & 1.88 & 1.95 & 1.99 \\
\hline 1.76 & 1.84 & 1.92 & 1.98 \\
\hline 1.70 & 1.81 & 1.89 & 1.95 \\
\hline 1.62 & 1.78 & 1.86 & 1.93 \\
\hline $1.50+\ell$ & 1.75 & 1.83 & 1.91 \\
\hline $1.50 \div \ell$ & 1.70 & 1.82 & 1.89 \\
\hline
\end{tabular}


TABLE XI

CALCULATED REDUCTION OF $\mathrm{PuO}_{2}$ BY CO$\mathrm{PuO}_{2}$ AT $1327^{\circ} \mathrm{C}\left(1600^{\circ} \mathrm{K}\right)$

\begin{tabular}{|c|c|c|c|c|}
\hline \multirow{3}{*}{$\begin{array}{c}\text { Graphite } \\
\text { Temperature } \\
\left({ }^{\circ} \mathrm{C}\right) \\
\end{array}$} & \multicolumn{4}{|c|}{ Equilibrium Stoichiometry $(\mathrm{O} / \mathrm{Pu})$} \\
\hline & \multicolumn{4}{|c|}{ CO Prossure (atm) } \\
\hline & $\underline{0.008}$ & $\underline{0.08}$ & 0.3 & 8.0 \\
\hline $82^{7}$ & 1.87 & 1.93 & 1.99 & 2.00 \\
\hline 927 & 1.82 & 1.89 & 1.95 & 1.99 \\
\hline 1027 & 1.78 & 1.85 & 1.92 & 1.98 \\
\hline 1127 & 1.73 & 1.82 & 1.89 & 1.95 \\
\hline 1227 & 1.65 & 1.78 & 1.86 & 1.93 \\
\hline 1327 & $1.50+\ell$ & 1.76 & 1.83 & 1.90 \\
\hline 1427 & $1.50 \div \ell$ & 1.72 & 1.81 & 1.88 \\
\hline 1527 & $1.50+2$ & 1.66 & $1.7 \mathrm{~s}$ & 1.86 \\
\hline
\end{tabular}

TABLE XI

CALCULATED REDUCTION OF $\mathrm{PUO}_{2}$ BY CO$\mathrm{PuO}_{2} \mathrm{AT} 1427^{\circ} \mathrm{C}\left(1700^{\circ} \mathrm{K}\right)$

Graphite

Temperature

$\left({ }^{\circ} \mathrm{C}\right)$

827

927

1027

1127

1227

1327

1427

1527
Equilibrium Stoichiometry $\left(\mathrm{O}_{1}^{\prime} \mathrm{Pu}\right)$

\begin{tabular}{cccc}
\hline \multicolumn{4}{c}{ CO Pressure (atm) } \\
\hline$\underline{0.008}$ & $\underline{0.08}$ & $\underline{0.80}$ & $\underline{8.0}$
\end{tabular}

$\begin{array}{llll}1.85 & 1.91 & 1.97 & 1.99\end{array}$

1. 80

1.87

1.93

1.98

1.76

1.83

1.90

1.96

1.70

1.79

1.87

1.93

$1.6 \mathrm{i}$

1.77

1.84

1.90

$1.50+\ell$

1.73

1.81

1.88

$1.50+2$

1.68

1.79

1.86

$1.50 \cdot \ell \quad 1.62$

1. 77

1.84 


\section{TABI,E XIII}

\section{CALCULATED REDUCTION OF $\mathrm{PuO}_{2}$ BY CO- $\mathrm{PuO}_{2}$ AT $1527^{\circ} \mathrm{C}\left(1800^{\circ} \mathrm{K}\right)$}

\begin{tabular}{c}
$\begin{array}{c}\text { Graphite } \\
\text { Temperature } \\
\left({ }^{\circ} \mathrm{C}\right)\end{array}$ \\
\hline 827 \\
927 \\
1027 \\
1127 \\
1227 \\
1327 \\
1427 \\
1527
\end{tabular}

\begin{tabular}{|c|c|c|c|}
\hline \multicolumn{4}{|c|}{ CO Pressure (atm) } \\
\hline 0.008 & 0.08 & 0.8 & 8.0 \\
\hline 1.83 & 1.90 & 1.95 & 1.99 \\
\hline 1.79 & 1.85 & 1.91 & 1.97 \\
\hline 1.74 & 1.82 & 1.88 & 1.94 \\
\hline $1.50+\ell$ & 1.76 & 1.82 & 1.89 \\
\hline $1.50+\ell$ & 1.75 & 1.82 & 1.88 \\
\hline $1.50+\ell$ & 1.71 & 1.80 & 1.86 \\
\hline $1.50+\ell$ & 1.65 & 1.78 & 1.84 \\
\hline $1.50+\ell$ & $1.50+\ell$ & 1.76 & 1.83 \\
\hline
\end{tabular}


TABLE XIV

EQUILIBRTMM PARTLA PIESEIIRES ABOVE < $\mathrm{PUO}_{2-\mathrm{X}}$ >

AT $927^{\circ} \mathrm{C}\left(1200^{\circ} \mathrm{K}\right)$

\begin{tabular}{|c|c|c|c|c|c|}
\hline \multirow[b]{2}{*}{$\begin{array}{l}\text { Stolchiometr; } \\
(\mathrm{O} / \mathrm{Pu})\end{array}$} & \multicolumn{5}{|c|}{$-\log P(a t n)$} \\
\hline & (O) & $\left(\mathrm{O}_{2}\right)$ & $(\mathrm{Pu})$ & (PuO) & $\left(\mathrm{PuO}_{2}\right)$ \\
\hline 2.00 & 18.12 & 21.04 & 25.20 & 18.19 & 16.95 \\
\hline 1.99 & 18.94 & $22.6 ?$ & 23.56 & 17.37 & 16.98 \\
\hline 1.98 & 19.24 & 23.28 & 22.96 & 17.07 & 16.99 \\
\hline 1.97 & 19.33 & 23.45 & 22.79 & 16.99 & 17.00 \\
\hline 1.96 & 19.43 & 23.65 & 22.59 & 16.89 & 17.00 \\
\hline 1.95 & 19.52 & 23.84 & 22.42 & 16.81 & 17.00 \\
\hline 1.94 & 19.62 & 24.04 & 22.22 & 16.71 & 17.01 \\
\hline 1.93 & 19.71 & 24.22 & 22.05 & 16.63 & 17.02 \\
\hline 1.92 & 19.82 & 24.43 & 21.85 & 16.53 & 17.03 \\
\hline 1.91 & 19.91 & 24.61 & 21.68 & 16.46 & i7. 04 \\
\hline 1.90 & 20.07 & 24.93 & 21.37 & 16.31 & 17.05 \\
\hline 1.89 & 20.14 & 25.07 & 21.24 & 16.24 & 17.06 \\
\hline 1.88 & 20.21 & 25.21 & 21.10 & 16.18 & 17.06 \\
\hline 1.87 & 20.28 & 25.36 & 20.96 & 16.11 & 17.07 \\
\hline 1.86 & 20.36 & 25.50 & 20.83 & 16.05 & 17.08 \\
\hline 1.85 & 20.43 & 25.65 & 20.70 & 15.99 & 17.09 \\
\hline 1.84 & 20.50 & 25.79 & 20.56 & 15.93 & 17.10 \\
\hline 1.83 & 20.57 & 25.94 & 20.43 & 15.87 & 17.12 \\
\hline 1.82 & 20.65 & 26.09 & 20.29 & 15.81 & 17.13 \\
\hline 1.81 & $2: .7 \%$ & 26.23 & 20.16 & 15.75 & 17.14 \\
\hline 1.80 & 20.78 & 26.38 & 20.03 & 15.69 & 17.16 \\
\hline 1.79 & 20.86 & 26.52 & 19.90 & 15.64 & 17.17 \\
\hline 1.78 & 20.93 & 26.66 & 19.78 & 15.58 & 17.19 \\
\hline 1.77 & 21.00 & 26.80 & 19.66 & 15.53 & 17.21 \\
\hline 1.76 & 21.07 & 26.94 & 19.54 & 15.48 & 17.22 \\
\hline 1.75 & 21.14 & 27.08 & 19.41 & 15.43 & 17.24 \\
\hline 1.74 & 21.19 & 27.18 & 19.33 & 15.39 & 17.25 \\
\hline 1.73 & 21.24 & 27.28 & 19.24 & 15.35 & 17.27 \\
\hline 1.72 & 21.29 & 27.37 & 19.15 & 15.31 & 17.28 \\
\hline 1.71 & 21.34 & 27.47 & 19.07 & 15.28 & 17.29 \\
\hline 1.70 & 21.39 & 27.57 & 18.99 & 15.24 & 17.31 \\
\hline 1.69 & 21.14 & 27.68 & 18.89 & 15.20 & 17.32 \\
\hline 1.68 & 21.50 & 27.79 & 18.80 & 15.17 & 17.34 \\
\hline 1.67 & 21.55 & 27.89 & 18.71 & 15.13 & 17.36 \\
\hline 1.66 & 21.61 & 28.00 & 18.63 & 15.10 & 17.38 \\
\hline 1.65 & 21.66 & 28.11 & 18.54 & 15.06 & 17.40 \\
\hline 1.64 & 21.74 & 28.27 & 18.40 & 15.01 & 17.43 \\
\hline 1.63 & 21.82 & 28.44 & 18.27 & 14.96 & 17.46 \\
\hline 1.62 & 21.90 & 28.60 & 18.14 & 14.91 & 17.49 \\
\hline 1.61 & 21.99 & 28.76 & 18.01 & 14.86 & 17.52 \\
\hline
\end{tabular}


TABLE XV

EQUILIRRIUM PARTIAL PRESSURES ABOVE $\left\langle\mathrm{PuO}_{2-\mathbf{x}}\right\rangle$ AT $1027^{\circ} \mathrm{C}\left(1300^{\circ} \mathrm{K}\right)$

$-\log P(a t m)$

Stoichiometry

\begin{tabular}{|c|c|c|c|c|c|}
\hline$(\mathrm{O} / \mathrm{Pu})$ & (0) & $\left(\mathrm{O}_{2}\right)$ & $(\mathrm{Pu})$ & (PuO) & $\left(\mathrm{PuO}_{2}\right)$ \\
\hline 2.00 & 15.25 & 17.00 & 24.63 & 17.12 & 15.02 \\
\hline 1.99 & 16.35 & 19.19 & 22.45 & 16.03 & 15.08 \\
\hline 1.98 & 16.70 & 19.89 & 21.76 & 15.69 & 15.09 \\
\hline 1.97 & 16.80 & 20.09 & 21.55 & 15.59 & 15.09 \\
\hline 1.96 & 16.92 & 20.33 & 21.32 & 15.47 & 15.10 \\
\hline 1.95 & 17.03 & 20.55 & $\therefore 1.11$ & 15.37 & 15.10 \\
\hline 1.94 & 17.15 & 20.79 & 20.87 & 15.26 & 15.11 \\
\hline 1.93 & 17.26 & 21.01 & 20.06 & 15.15 & 15.11 \\
\hline 1.92 & 17.33 & 21.26 & 20.42 & is. 04 & 1513 \\
\hline 1.91 & 17.50 & 21.49 & 20.22 & 14.95 & 15.15 \\
\hline 1.90 & 17.67 & 21.83 & 19.88 & 14.78 & 15.15 \\
\hline 1.89 & 17.76 & 22.01 & 19.70 & 14.70 & 15.16 \\
\hline 1.88 & 17.85 & 22.19 & 19.53 & 14.62 & 15.17 \\
\hline 1.87 & 17.94 & 22.38 & 19.36 & 14.54 & 15.18 \\
\hline I. 86 & 18.04 & 22.56 & 19.19 & 14.46 & 15.19 \\
\hline 1.85 & 18.13 & 22.74 & 19.62 & 14.38 & 15.21 \\
\hline 1.84 & 18.22 & 22.93 & 18.85 & 14.30 & 15.22 \\
\hline 1.83 & 18.31 & 23.11 & 18.69 & 14.22 & 15.24 \\
\hline 1.82 & 18.40 & 23.30 & 18.51 & 14.15 & 15.25 \\
\hline 1.81 & 18.50 & 23.48 & 18.35 & 14.07 & 15.27 \\
\hline 1.80 & 18.59 & 23.66 & 18.18 & 14.00 & 15.29 \\
\hline 1.79 & 18.67 & 23.84 & 19.03 & 13.93 & 15.31 \\
\hline 1.78 & 18.76 & 24.01 & $17 . \varepsilon 7$ & 13.86 & 15.33 \\
\hline 1.77 & 18.85 & 24.18 & 17.72 & 13.80 & 15,35 \\
\hline 1.76 & 18.93 & 24.36 & 17.57 & 13.73 & 15.37 \\
\hline 1.75 & 19.02 & 24.53 & 17.42 & 13.67 & 15.39 \\
\hline 1.74 & 19.08 & 24.64 & 17.32 & 13.63 & 15.41 \\
\hline 1.73 & 19.13 & 24.75 & 17.22 & 13.58 & 15.42 \\
\hline 1.72 & 19.19 & 24.86 & 17.12 & 13.54 & 15.43 \\
\hline 1.71 & 19. 24 & 24.98 & 17.03 & 13.50 & 15.45 \\
\hline 1.70 & 19.30 & 25.09 & 16.93 & 13.46 & 15.46 \\
\hline 1.69 & 19.35 & 25.19 & 16.85 & 13.43 & 15,48 \\
\hline 1,68 & 19.40 & 25.29 & 16.76 & 13.39 & 15.50 \\
\hline 1.67 & 19.45 & 25.39 & 16.68 & 13.36 & 15.51 \\
\hline 1.66 & 19.50 & 25.50 & 16.59 & 13.33 & 15.53 \\
\hline 1.65 & 19.55 & 25.60 & 16.51 & 13.29 & 15.55 \\
\hline 1.64 & 14. & 25.74 & 16.39 & 13.25 & 15.57 \\
\hline 1.63 & 19. is & 25.89 & 16.27 & 13.20 & 15.60 \\
\hline 1.62 & 19.77 & $\therefore .03$ & 16.15 & 13.16 & 15.63 \\
\hline 1.61 & 19.84 & $26.2 i$ & 16.01 & 13.11 & 15.66 \\
\hline
\end{tabular}


TABLE XVI

EQUILIBRIUM PARTIAL PRESSURES ABOVE $<\mathrm{PuO}_{2-x}>$ AT $1127^{\circ} \mathrm{r}\left(1400^{\circ} \mathrm{K}\right)$

Stolchiometry

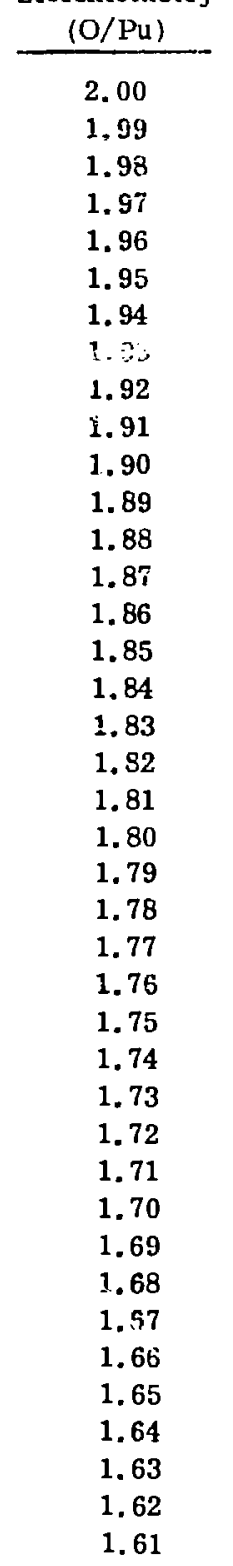

\section{$-\log P(a t m)$}

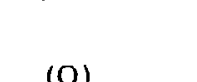

$\frac{(0)}{12.80}$

$\underline{\left(\mathrm{O}_{2}\right)}$

13.54

14.13

14.52

14.63

14.77

14.89

15.03

15.16

15.30

15.43

15.01

15.72

15.83

15.94

16.05

16.15

16.26

16.37

16.48

16.59

16. 70

16.80

16. 30

17.00

17. 10

17.20

17.26

17.32

17.38

17.45

17.51

17.56

17.60

17.65

17.70

17.75

17.81

17.88

17.94

18.00
16.20

16.98

17. 2 :

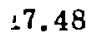

17.73

18.00

18.26

18.54

13.81

19.18

19. 39

19.61

19.82

20.04

20.26

20.47

20.69

20.31

21.12

21.34

21.54

21.74

21.95

22.15

22.35

22.47

22.59

22.72

22.84

22.96

23.06

23.15

23.25

23.35

23.45

23.57

23.70

23.83

23.95
(Pu)

24.14

21.49

$-\because 2$

20.49

20.23

i9. 99

19.72

19.47

19.20

13.96

18.60

18.39

18. 19

17.98

17.78

17.58

17.38

17.18

16.99

16.79

16.60

16.41

16.23

16.05

15.88

15.70

15.59

15.49

15. 38

15.28

15.17

15.08

15.01

14.93

14.85

14.77

14.66

14.56

14.45

14.35
(PuO)

16.20

i4. 87

14.50

14.39

14.26

14.14

14.01

13.89

13.75

13.65

13. 47

13. 37

13. 28

13. 18

13.09

13.00

12.91

12. 81

12.73

12.64

12.55

12,47

12.39

12.31

12.24

12.16

12. 12

12.07

12.03

11.98

11.94

11.90

11.87

11.84

11.81

11.78

11.73

11.69

11.65

11.62
(PuO)

33. 37

13.44

13.45

13.46

13.46

13.47

13.47

13.48

13.50

13.52

13.53

13.54

13.55

13.56

13.58

13.59

13.61

13. 63

13.64

13.67

13.69

13.71

13. 73

13. 75

13. 78

13.81

13.82

13.83

13.85

13.87

13.89

13.90

13.92

13.93

13.95

13.97

13.99

14.01

14.04

14.06 
TABLE XVII

EQUILIBRIJM PARTIAL PRESSURES ABOVE $\left\langle\mathrm{PuO}_{2-\boldsymbol{x}}\right.$ >

AT $1227^{\circ} \mathrm{C}\left(1500^{\circ} \mathrm{K}\right)$

\begin{tabular}{|c|c|c|c|c|c|}
\hline \multirow{2}{*}{$\begin{array}{l}\text { Stoichiometry } \\
(\mathrm{O} / \mathrm{Pu}) \\
\end{array}$} & \multicolumn{5}{|c|}{$-\log P(a t m)$} \\
\hline & (O) & $\left(\mathrm{O}_{2}\right)$ & (Pu) & (PuO) & $\left(\mathrm{PuO}_{2}\right)$ \\
\hline 2.00 & 10.66 & 10.54 & 23.72 & 15.40 & 11.94 \\
\hline 1.99 & 12.20 & 13.61 & 20.65 & 13.87 & 12.02 \\
\hline 1.98 & 12.62 & 14.46 & 19.82 & 13.47 & 12.04 \\
\hline 1.97 & 12.75 & 14.72 & 19.57 & 13. 34 & 12.04 \\
\hline 1.96 & 12.90 & 15.01 & 19.28 & 13.20 & 12.05 \\
\hline 1.95 & 13.04 & 15.29 & 19.01 & 13.07 & 12.06 \\
\hline 1.94 & 13.19 & 15.59 & 18.72 & 12.92 & 12.06 \\
\hline 1.93 & 13.33 & 15.87 & 18.44 & 12.79 & 12.07 \\
\hline 1.92 & 13.49 & 16.19 & 18.14 & 12.65 & 12.09 \\
\hline 1.91 & 13.64 & 15.49 & 17.87 & 12.52 & 12.11 \\
\hline 1.90 & 13.83 & 16.88 & 17.48 & 12.34 & 12.12 \\
\hline 1.89 & 13.96 & 17.12 & 17.25 & i2.22 & 12.13 \\
\hline 1.88 & 14.08 & 17.37 & 17.02 & 12.12 & 12.14 \\
\hline 1.87 & 14.20 & 17.51 & 16.79 & 12.01 & 12.16 \\
\hline 1.86 & 14.32 & 17.86 & 16.56 & 11.90 & 12.17 \\
\hline 1.85 & 14.45 & 18.10 & 16.34 & 11.80 & 12.19 \\
\hline 1.84 & 14.57 & 18.35 & 16.11 & 11.70 & 12.21 \\
\hline 1.83 & 14.69 & 18.59 & 15.88 & 11.59 & 12.23 \\
\hline 1.82 & 14.81 & 18.83 & 15.66 & 11.49 & 12.25 \\
\hline 1.81 & 14.94 & 19.08 & 15.44 & 11.39 & 12.28 \\
\hline 1.80 & 15.06 & 19.32 & 15.22 & 11.30 & 12.30 \\
\hline 1.79 & 15.17 & 19.55 & 15.02 & 11.21 & 12.32 \\
\hline 1.78 & 15.28 & 19.78 & 14.81 & 11.12 & 12.35 \\
\hline 1.77 & 15.40 & 20.01 & 14.61 & 11.03 & 12.37 \\
\hline 1.76 & 15.51 & 20.23 & 14.41 & 10.94 & 12.40 \\
\hline 1.75 & 15.63 & 20.46 & 14.22 & 10.86 & 12.43 \\
\hline 1.74 & 15.69 & 20.59 & 14.10 & 10.81 & 12.45 \\
\hline 1.73 & 15.76 & 20.72 & 13.98 & 10.76 & 12.46 \\
\hline 1.72 & 15.82 & 20.85 & 13.87 & 10.71 & 12.48 \\
\hline 1.71 & 15.89 & 20.99 & 13. 76 & 10.66 & 12.50 \\
\hline 1.70 & 15.95 & 21.12 & 13.64 & 10.62 & 12.52 \\
\hline 1.69 & 16.00 & 21.21 & 13.57 & 10.58 & 12.53 \\
\hline 1.68 & 16.05 & 21.30 & 13.49 & 10.55 & 12.55 \\
\hline 1.67 & 16.09 & 21.40 & 13.41 & 10.22 & 12.56 \\
\hline 1.66 & 16.14 & 21.49 & 13.33 & 10.49 & 12.58 \\
\hline 1.65 & 16.19 & 21.58 & 13.26 & 10.46 & 12.60 \\
\hline 1.64 & 16.24 & 21.70 & 15.16 & 10.42 & 12.61 \\
\hline 1.63 & 16.30 & 21.81 & 13.07 & 10.39 & 12.63 \\
\hline 1.62 & 16.36 & 21.92 & 12.98 & 10.35 & 12.66 \\
\hline 1.61 & 16.41 & 22.03 & 12.89 & 10.32 & 12.68 \\
\hline
\end{tabular}


TABLE XVIII

EQUILIDRIUM PARTIAL PRESEURRS ABOVE $<\mathrm{PUO}_{2-\mathrm{x}}$ >

AT $1327^{\circ} \mathrm{C}\left(1600^{\circ} \mathrm{K}^{\circ}\right)$

\begin{tabular}{|c|c|c|c|c|c|}
\hline \multirow{2}{*}{$\begin{array}{l}\text { Stolchiometry } \\
(\mathrm{O} / \mathrm{Pu})\end{array}$} & \\
\hline & (O) & $\left(\mathrm{O}_{2}\right)$ & $(\mathrm{Pu})$ & (PuO) & $\left(\mathrm{PuO}_{2}\right)$ \\
\hline 2.00 & 8.80 & 7.92 & 23.35 & 14.71 & $10.7 \%$ \\
\hline 1.99 & 10.59 & 11.35 & 19.92 & 13.00 & 10.78 \\
\hline 1.98 & 10.97 & 12.26 & 19.03 & 12.56 & 10.80 \\
\hline 1.97 & 11.11 & 12.54 & 18.76 & 12.43 & $10.8 ?$ \\
\hline 1.96 & 11.27 & 12.85 & 18.45 & 12.28 & 10.81 \\
\hline 1.95 & 11.42 & 13.15 & 18.16 & 12.13 & 10.82 \\
\hline 1.94 & 11.58 & 13.48 & 17.84 & 11.98 & 10.82 \\
\hline 1.93 & 11.74 & 13.79 & 17.54 & 11.83 & 10.84 \\
\hline i. 92 & 11.92 & 14.16 & 17.18 & 11.67 & 10.85 \\
\hline 1.91 & 12.07 & 14.46 & 16.91 & 11.54 & 10.87 \\
\hline 1.90 & 12.28 & 14.87 & 16.51 & 11.34 & 10.88 \\
\hline 1.89 & 12.41 & 15.14 & 16.25 & 11.22 & 19.90 \\
\hline 1.88 & 12.55 & 15.41 & 15.99 & 11.10 & 10.91 \\
\hline 1.87 & 12.68 & 15.68 & $15.7 d$ & 10.98 & 10.93 \\
\hline 1.86 & 12.81 & 15.95 & 15.49 & 10.87 & 10.95 \\
\hline 1.85 & 12.95 & 16.22 & 15.24 & 10.75 & 10.97 \\
\hline 1.84 & 13.08 & 16.49 & 14.99 & 10.64 & 10.99 \\
\hline 1.83 & 13.22 & เ6.75 & 14.74 & 10.52 & 11.01 \\
\hline 1.82 & 13.35 & 17.02 & 14.50 & 10.41 & 11.03 \\
\hline 1.81 & 13.49 & 17.29 & 14.26 & 10.30 & 11.06 \\
\hline 1.80 & 13.62 & 17.56 & 14.02 & 10.20 & 11.09 \\
\hline 1.79 & 13.75 & 17.81 & 13.79 & 10.10 & 11.11 \\
\hline 1.78 & 13.87 & 18.06 & 13.57 & 10.00 & 11.14 \\
\hline 1.77 & 14.00 & 18.31 & 13.35 & 9.90 & 11.17 \\
\hline 1.76 & 14.12 & 18.56 & 13.13 & 9.81 & 11.20 \\
\hline 1.75 & 14.25 & 18.81 & 12.91 & 9.72 & 11.23 \\
\hline 1.74 & 14.32 & 18,95 & 12.79 & 9.66 & 11.24 \\
\hline 1.73 & 14.39 & 19.09 & 12.67 & 9.61 & 11.25 \\
\hline 1.72 & 14.46 & 19.23 & 12.54 & 9.56 & 11.28 \\
\hline 1,71 & 14.52 & 19.37 & 12.42 & 9.51 & 11.30 \\
\hline 1.70 & $14.5 \bar{y}$ & 19.51 & 12.31 & 9.46 & 11.32 \\
\hline 1.69 & 14.64 & 19.59 & 12.23 & 9.43 & 11.33 \\
\hline 1.68 & 14.68 & 19.68 & 12.12 & $y, 40$ & 11.35 \\
\hline 1.67 & 14.73 & 19.77 & 12.08 & 9.37 & 11.36 \\
\hline 1.66 & 14.77 & 19.86 & 12.01 & 9.34 & 11.38 \\
\hline 1.65 & 14.82 & 19.95 & $\geq 1.93$ & 9.31 & 11.39 \\
\hline 1.64 & 14.87 & 20.05 & 11.85 & 9.28 & 11.41 \\
\hline 1.63 & 14.92 & 20.15 & 11.77 & 9.24 & 11.43 \\
\hline 1.62 & 14.97 & 20.25 & 11.68 & 9.21 & 11.45 \\
\hline 1.61 & 15.02 & 20.35 & 11.60 & 9.18 & 11.47 \\
\hline
\end{tabular}


TABIE XiX

EQUUIIBRIUN PAHTLAL PRESSURES ABR $V$ E $<\mathrm{JUO}_{2-x}>$

$A^{\prime} T 1427^{\circ} \mathrm{C}\left(1700^{\circ} \mathrm{K}\right)$

Stolchiometry

$(\mathrm{O} / \mathrm{Pu})$

2.00

1.99

1.98

1.97

$\therefore .96$

1.95

1.94

1.93

i. 92

1.91

1.90

1.89

1.88

1.87

1.36

1. 85

1.84

1.83

1.82

i. 81

1.80

1.79

1.78

1.77

1.75

1.75

1.74

1.73

1.72

1.71

1.70

1.69

1.68

1. 67

1.63

1.65

1.64

1.63

1.62

1.61

$-\log p(a t u n)$

\begin{tabular}{|c|c|c|c|c|}
\hline (O) & $\left(\mathrm{O}_{2}\right)$ & $(\mathrm{Pu})$ & (PuO) & $\left(\mathrm{PuO}_{n !}\right.$ \\
\hline 7.16 & 5.60 & 23.01 & 14.09 & 9.63 \\
\hline 9.03 & 9.36 & 19.27 & 12.23 & 9.69 \\
\hline 9.51 & 10.31 & 18.33 & 11.77 & 9.70 \\
\hline 9.66 & 10.61 & 18.09 & 11.67 & 9.71 \\
\hline 9.83 & 10.95 & 17.71 & 11.46 & 9.72 \\
\hline 9.99 & 11.27 & 17.40 & 11.31 & 9.73 \\
\hline i0.16 & 11.62 & 17.18 & 11.20 & 9.73 \\
\hline 10.33 & 11.95 & 16.73 & 10.99 & 9.75 \\
\hline 10.51 & 12.32 & 16.38 & 10.82 & 9.76 \\
\hline 10.69 & $12 . ? 7$ & 16.06 & 10.67 & 9.79 \\
\hline 10.90 & $1: 09$ & 15.64 & 10.46 & 9.80 \\
\hline 11.05 & 13.39 & 15.36 & 10.33 & 9.81 \\
\hline 11.19 & 13.68 & 15.09 & 10.20 & 9.82 \\
\hline 11.34 & 13.97 & 14.81 & 10.07 & 9.84 \\
\hline $11 \therefore 0$ & 14.26 & 14.54 & 9.95 & 9.86 \\
\hline 11.63 & 14.55 & 14.27 & 9.83 & 9.89 \\
\hline 11.78 & 14.85 & 14.00 & 9.70 & 9.91 \\
\hline 11.92 & 15.14 & 13.72 & 9.58 & 9.93 \\
\hline 12.07 & 15.43 & 13.35 & 9.46 & 9.96 \\
\hline 12.21 & 15.72 & 13.21 & S. 34 & 9.99 \\
\hline 12.36 & 16.01 & 12.95 & 9.23 & 10.02 \\
\hline 12.49 & 16.28 & 12.70 & 9.12 & 10.04 \\
\hline 12.63 & 16.55 & 12.46 & 9.01 & 10.07 \\
\hline 12.76 & 16.81 & 12.23 & 8.91 & 10.10 \\
\hline 12.89 & 17.08 & 11.99 & 8.81 & 10.13 \\
\hline 13.03 & 17.35 & 11.76 & 8.71 & 10.17 \\
\hline 13.10 & 17.50 & 11.63 & 8.65 & 10.18 \\
\hline 13.18 & 17.64 & 11.50 & 8.60 & 10.20 \\
\hline 13.25 & 17.79 & 11.37 & 8.54 & 10.22 \\
\hline 13.32 & 17.94 & 11.24 & 8.49 & 10.24 \\
\hline $13.4 \mathrm{C}$ & 18.08 & 11,12 & 8.44 & 10.26 \\
\hline 13.44 & 18.17 & $13 . \div 5$ & 8.41 & 10.28 \\
\hline 13.48 & 18.26 & $10.5 i$ & 8.38 & 10.29 \\
\hline 13.52 & 18.34 & 10.90 & 8.35 & 10.30 \\
\hline 13.57 & 18.43 & 10.82 & 8.31 & 10.31 \\
\hline 13.61 & 18.52 & 10.76 & 829 & 10.34 \\
\hline 13.66 & 18.61 & 10.69 & 8.26 & 10.35 \\
\hline 13.70 & 18.70 & 10.61 & 8.24 & $10.3 i$ \\
\hline 13.75 & 18.78 & 10.54 & 8.21 & 10.35 \\
\hline 13.79 & 18.87 & 10.47 & 8.18 & 10.40 \\
\hline
\end{tabular}


TABLE XX

EQUILIBRIUM PARTLAI PRESEURES ABOVE $<$ PLO $\mathrm{O}_{z-\mathrm{x}}$ "

AT $1527^{\circ} \mathrm{C}\left(1800^{\circ} \mathrm{K}\right)$

Stolchiometry

(O/Pu)

2.00

1.99

1.98

1.97

1.96

1.95

1.94

1.93

i. 92

1.91

1.90

1.89

1.88

1.87

1.86

1. 85

1.84

1.83

1.82

1.81

1.80

1.79

1.78

1.77

1.76

1. 75

1.74

1.73

1.72

1.71

1.79

1.69

1.68

1.67

1.66

1.65

1.64

1.63

1.62

1.61

$-\log F(a t m)$

\begin{tabular}{|c|c|c|c|c|}
\hline (O) & $\left(\mathrm{O}_{2}\right)$ & (Pu) & (PuO) & $\left(\mathrm{PuO}_{2}\right)$ \\
\hline 5.69 & 3.16 & 22.72 & 13.54 & 8.67 \\
\hline 7.71 & 7.58 & 18.69 & 11.54 & 8.72 \\
\hline 8.21 & 8.59 & 17.71 & 11.06 & 8.73 \\
\hline 8.37 & 8.91 & 17.40 & 10.91 & 8.74 \\
\hline 6.55 & 5.26 & 17.06 & 10.74 & 8.75 \\
\hline 8.72 & 9.60 & 16.72 & 10.57 & 8.76 \\
\hline 3.90 & 9.97 & 16.36 & 10.40 & 8.76 \\
\hline 9.08 & 10.32 & 16.02 & 10.23 & 8.78 \\
\hline 5.27 & 10.71 & 15.65 & 10.06 & 8.79 \\
\hline 9.46 & 11.08 & 15.30 & 5.89 & 8.82 \\
\hline 9.68 & $11.5 \bar{z}$ & 14.87 & 9.68 & 8.83 \\
\hline 9.83 & 11.83 & 14.57 & 9.54 & 8.84 \\
\hline 9.90 & 12.14 & 14.28 & $9.4 n$ & 8.86 \\
\hline 10.15 & 12.45 & 13.99 & 9.27 & 8.88 \\
\hline 10.30 & 12.77 & 13.70 & 9.13 & 8.90 \\
\hline 10.46 & 13.08 & 13.41 & 9.00 & 8.93 \\
\hline 10.61 & 13.39 & 13.12 & 8.87 & 8.95 \\
\hline 10.77 & 13.70 & 12.84 & 8.74 & 8.97 \\
\hline 10.92 & 14.01 & 12.55 & 6.61 & 9.00 \\
\hline 11.08 & 14.32 & 12.27 & 8.49 & 0.03 \\
\hline 11.23 & 14.6 .3 & 12.00 & 8.37 & 3.06 \\
\hline 11.38 & 14.92 & 11.74 & 8.25 & 9.09 \\
\hline 11.52 & 15.20 & 11.40 & 8.14 & 9.12 \\
\hline 11.36 & 15.49 & 11.23 & 8.02 & 9.15 \\
\hline 11.80 & 15.77 & 10.96 & $7 y$ & 9.17 \\
\hline 11,95 & 16.06 & 10.73 & 7.81 & 9.23 \\
\hline 12.02 & 16.21 & 10.59 & 7.75 & 9.24 \\
\hline 12.10 & 16.36 & 10.46 & 7.69 & 9.26 \\
\hline 12.18 & 16.52 & 10.33 & 7.64 & 9.28 \\
\hline 12.25 & 16.67 & 10.27 & 7.58 & 9. 30 \\
\hline 12.33 & 16.82 & 10.07 & 7.53 & 9.35 \\
\hline 12.37 & 16.91 & 9.99 & 7.50 & 9. 34 \\
\hline 12.41 & 16.99 & 9.92 & 7.47 & 9.35 \\
\hline 12.45 & 17.07 & 9.85 & 7.44 & 9.36 \\
\hline 12.50 & 17,16 & 9.78 & 7.42 & 9.38 \\
\hline 12.54 & 17.24 & 9.72 & 7.39 & 9.39 \\
\hline 12.58 & 17.32 & 9.65 & 7.36 & 9.41 \\
\hline 12.62 & 17.40 & 9.58 & 7.34 & 9.42 \\
\hline 12.66 & 17.48 & 9.52 & 7.31 & 9. 44 \\
\hline 12.72 & 17.56 & 9.46 & 7.29 & $\therefore .45$ \\
\hline
\end{tabular}


TABLE XXI

$<\mathrm{PUO}_{2}>\mathrm{X}$ STOICLIOMETRIES THAT LEAD TO PU. VAPOR PRESSURES HIGH ENOUGH TO FORM THE LISTED COMPOUNUS

\begin{tabular}{|c|c|c|c|c|c|}
\hline $\begin{array}{l}\text { Temp } \\
\left({ }^{\circ} \mathrm{C}\right) \\
\end{array}$ & $\leqslant \mathrm{PuIr}_{2}>$ & $\leq \mathrm{PuPt}_{3}>$ & $\left\langle\mathrm{PuPt}_{\phi_{2}}\right\rangle$ & $\left\langle\mathrm{PuPt}_{\overline{5}}\right\rangle$ & $\left\langle\mathrm{PuRh}_{3}\right\rangle$ \\
\hline 327 & - & --- & $-\infty$ & $-\infty$ & 1.67 \\
\hline 1027 & 1.62 & $-\cdots$ & $-\infty$ & -- & 1.67 \\
\hline 1127 & 1.64 & $-\infty$ & $-\cdots$ & 1.62 & 1.67 \\
\hline 1227 & 1.67 & 1.61 & 1.63 & 1.69 & 1.67 \\
\hline 1327 & 1.70 & 1.63 & 1.69 & 1.75 & 1.57 \\
\hline 1427 & 1. 72 & 1.66 & 1.72 & 1.77 & 1.67 \\
\hline 1527 & 1.73 & 1.68 & 1.75 & 1.79 & 1.67 \\
\hline
\end{tabular}

